\title{
Centromere-specific histone Cse4 by the chaperone $\mathrm{Scm} 3$
}

\author{
Uhn-Soo Cho ${ }^{*}$, Stephen C Harrison ${ }^{2}$ \\ From Epigenetics and Chromatin: Interactions and processes \\ Boston, MA, USA. 11-13 March 2013
}

\begin{abstract}
A specialized nucleosome is a component of all eukaryotic kineto-chores. The core of this nucleosome contains a centromere-specific histone, CENP-A (the Cse4 gene product in budding yeast), instead of the usual H3. Assembly of a centromeric nucleosome depends on a specific chaperone, called $\mathrm{Scm} 3$ in yeast and HJURP in higher eukaryotes. We describe here the structure of a complex formed by an N-terminal fragment of Scm 3 with the histone-fold domains of Cse4, and H4, all prepared as recombinant proteins derived from the budding yeast Kluyveromyces lactis. The contacts of Scm3 with Cse4 explain its selectivity for the centromere-specific histone; key residues at the interface are conserved in HJURP, indicating a common mechanism for centromeric histone deposition. We also report the structure of a (Cse4:H4) $)_{2}$ heterotetramer; comparison with the structure of the Scm3:Cse4:H4 complex shows that tetramer formation and DNA binding require displacement of Scm3 from the nucleosome core. The two structures together suggest that specific contacts between the chaperone and Cse4, rather than an altered overall structure of the nucleosome core, determine the selective presence of Cse 4 at centromeres.
\end{abstract}

\section{Author details}

'Department of Biological Chemistry, University of Michigan, Ann Arbor, Ml 48109, USA. ${ }^{2}$ Department of Biological Chemistry and Molecular Pharmacology and Howard Hughes Medical Institute, Harvard Medical School, Boston, MA 02115, USA.

Published: 18 March 2013

doi:10.1186/1756-8935-6-S1-P95

Cite this article as: Cho and Harrison: Centromere-specific histone Cse4 by the chaperone Scm3. Epigenetics \& Chromatin 2013 6(Suppl 1):P95.

'Department of Biological Chemistry, University of Michigan, Ann Arbor, Ml 48109, USA

Full list of author information is available at the end of the article

Submit your next manuscript to BioMed Central and take full advantage of:

- Convenient online submission

- Thorough peer review

- No space constraints or color figure charges

- Immediate publication on acceptance

- Inclusion in PubMed, CAS, Scopus and Google Scholar

- Research which is freely available for redistribution 